\title{
IMPACT OF INDUSTRIAL SECTOR ON GDP (PAKISTAN CASE)
}

\author{
Muhammad Ajmair \\ Assistant Professor, Department of Economic, Mirpur University of Science and \\ Technology (MUST) Bhimber Campus AJ\&K.
}

Doi: 10.19044/elp.v1no1a8 URL:http://dx.doi.org/10.19044/elp.v1no1a8

\begin{abstract}
This study is an attempt to investigate the relationship between economic growth and different components of industrial sector of the economy of Pakistan. For this purpose the secondary data for 61 years from 1950 to 2010 is used. The first step in the empirical analysis involves testing the time series characteristics of the data series using ADF tests. Simple linear regression and time series techniques are applied to estimate the relationships. All the variables used in this study are stationary in their first differences. Regarding the hypotheses of the study it is concluded that the entire hypothesis, has a positive impact on GDP, partially accepted. Because in simple linear regression all the components of industrial sector show a positive relationship with GDP except mining and quarrying sector that not only shows the negative relationship but also gives an insignificant result. All other results are statistically significant and consistent in simple linear regression.
\end{abstract}

JEL Classification A-10

Keywords: GDP, Industrial sector

\section{1-Introduction}

\section{1-Background}

The economy of Pakistan is $47^{\text {th }}$ largest in the world in nominal terms and $25^{\text {th }}$ in the world in term of purchasing power parity (PPP). The economy of Pakistan can broadly be described into three sectors agricultural, industrial and services sectors. The agricultural sector contributes around 21 percent, industrial 19 percent, and services sector 53 percent in GDP. Pakistan has a semi- industrialized economy which encompasses textiles, chemical, food processing, agriculture and other industries. In 1947 when Pakistan came into existence its industrial sector was very limited at that 
time but as time passed this sector of economy flourished. Today Pakistan ranks 41 in the World and 55 Worldwide in factory output and industrial sector accounts for about 26 percent of GDP. The share of industrial sector in the country's GDP has increased by 0.40 percentage point in the outgoing fiscal and that of agriculture and services sector has slightly declined according to latest official survey report. (Wikipedia, Economy of Pakistan 2010).

Pakistan's major industries included cement, fertilizer, edible oil, sugar, steel, tobacco, chemicals, machinery, food processing, textile and apparel manufacturing. Cotton textile production and manufacturing are Pakistan's largest industries accounting for about 64 percent of total export and account for 40 percent of employed labor force. The contribution of traditional product such as textile and fibers, leather, food and tobacco, are the major industries in terms of their contribution to value addition 43.2 percent in 1998 and 38.8 percent in 2007 . The shares of these industries dominate whole industrial sector.

At the ground level the SMEs and the large firms are equally ignorant and careless about their role in environmental degradation in Pakistan. This is essentially due to poor institutional capacity and little emphasis on environment in fiscal policy and insufficient allocation of funds for environmental protection of forestry, biodiversity, water and sanitation. The Mid Term Development Framework (MTDF: 2005-10) has laid down the long term objective of sustainable economic growth without environmental degradation (GOP, 2005). Its real success would depend on how effectively the environmental laws cover the National Environmental Quality Standards (NEQS) and whether or not the violators of the laws are made to pay for damaging the environment.

While the government of Pakistan needs to promote the industry in the country, and simultaneously is a custodian to environmental protection, there is a need for national environmental legislation on the leather industry; local laws could be introduced to curb the growing tannery effluent problem. In fact, certain industrial areas are suffering greater environmental damage and would benefit from local legislation. For example, in Karachi, the Korangi Industrial Area has the largest number of tanneries working in the leather sector and is the most polluted area with "open drains and effluent being discharge without treatment. 
In recent years the country has seen rapid growth in industries such as apparel, textile and cement and services (such as telecommunication, transportations, advertising, and finance). Strong state involvement persists in services especially in transport, communication and life insurance, while account for well over half of Pakistan's GDP and substantial employment.

( Wikipedia, Economy of Pakistan 2010)

\section{CHART-1-Time trend of industrial sector}

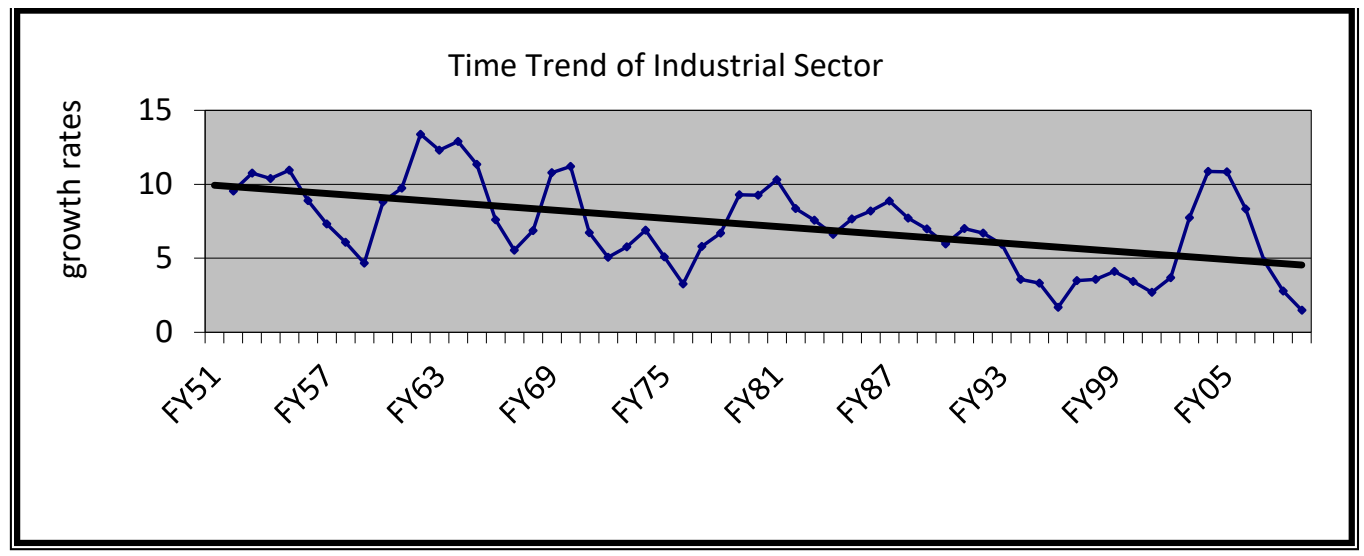

\section{2-DEFINITIONOF GDP}

"GDP measures the total output produced within a country's borders whether produced by that country's own firms or not during a specific time period that is usually one year."

The gross domestic product (GDP) is the godfather of the indicator world. As an aggregate measure of total economic production for a country, GDP represents the market value of all goods and services produced by the economy during the period measured, including personal consumption, government purchases, private inventories, paid-in construction costs and the foreign trade balance (exports are added, imports are subtracted).(www.investopedia.com 2011)

\section{3-IMPORTANCE OF INDUSTRIAL SECTOR}

The credit goes to industrialization which has dethroned the poverty and has made the people of developed countries like US, UK, Canada, Germany and Japan to enjoy the higher standard of living. This is the reason the wave of industrialization has also entered in the Far Eastern countries, known as "Newly Industrializing Countries" (NICs). It has been a desire on our part to start and perpetuate the process of industrialization. The importance of industrialization for our country is obvious from the following reasons:-

Increase in employment opportunities, Increase in output and incomes, Agriculture development, Development of allied and related 
sectors, Attainment of internal and external economies, Industrialization brings social and economic changes, Industrialization will reduce BOP deficit, The increased saving and investment, Increase government revenues and Defense requirements. (www.scribd.com 2011)

\section{4- COMPONENT OF PAKISTAN INDUSTRIAL SECTOR}

The components of Pakistan's industrial sector are as follows:

1- Mining and quarrying

2- Fuel extraction industry

3- Manufacturing

4- Construction

5- Electricity, gas and water supply

\subsection{1-Mining and Quarrying}

Mining is the extraction of raw materials from the Earth's crust, usually from an ore body, vein or (coal) seam. Mining produces three types of mineral body, commodities-metals, industrial minerals, and fuels-that all countries find essential for maintaining and improving their standards of living. Mining is basic to the human way of living, as essentially everything we use in modern society (that does not come from a plant) is a product of mining sector.

However, the direct and indirect contribution that the mining industry makes to human prosperity is often not as well recognized, as it should be. Minerals are also unique in the sense of their non- renewable profile, as mineral deposited are finite, either physically or economically. This implies a special concern about their exploitation, and consumption in a way that could prevent or mitigate their scarcity or unavailability for future generations. (Umer Sheraz 2010 ; Mining Futures: Beyond the Headlines)

Pakistan has a widely varied geological framework, ranging from pre- Cambrian that includes a number of zones hosting several metallic minerals industrial minerals precious and semi- precious stones. The mining and quarrying sector is estimated to grow by 0.4 percent in 2010-2011 as against 2.2 percent in the last year. (Economic Survey 2010-2011)

Important minerals found in Pakistan are gypsum, limestone, chromites, iron ore, rock, salt, silver, gold, precious stones, gems, marble, copper, coal, graphite, sulpher, fire clay, silica. The ministry of Petroleum of Natural Resources formulates and implements petroleum, gas and mining policies. All minerals except petroleum and nuclear minerals are constitutionally owned by the Provinces. Federal govt.'s role is to provide geological data, assist in provincial coordination, and to facilitate foreign investment in the mining sector. It also finances mineral projects. The govt. 
remains keen to attract foreign operations, including joint ventures. (Wikipedia 2010, Industry of Pakistan)

The main Pakistan mining operation, Saindak Metal Limited is state owned and produces copper, gold, silver, blister copper is exported. In November 2002, it was leased for ten years to a China firm under a US \$ 350 million. The Pakistan Mineral Development Corporation (PMDC) four coal mines (10 percent of the country's coal deposits), four salt mines/ quarries (45 percent of total production) and silica sand quarry.(www.wto.org 2010)

CHART - 2- Time trend of mining and quarrying

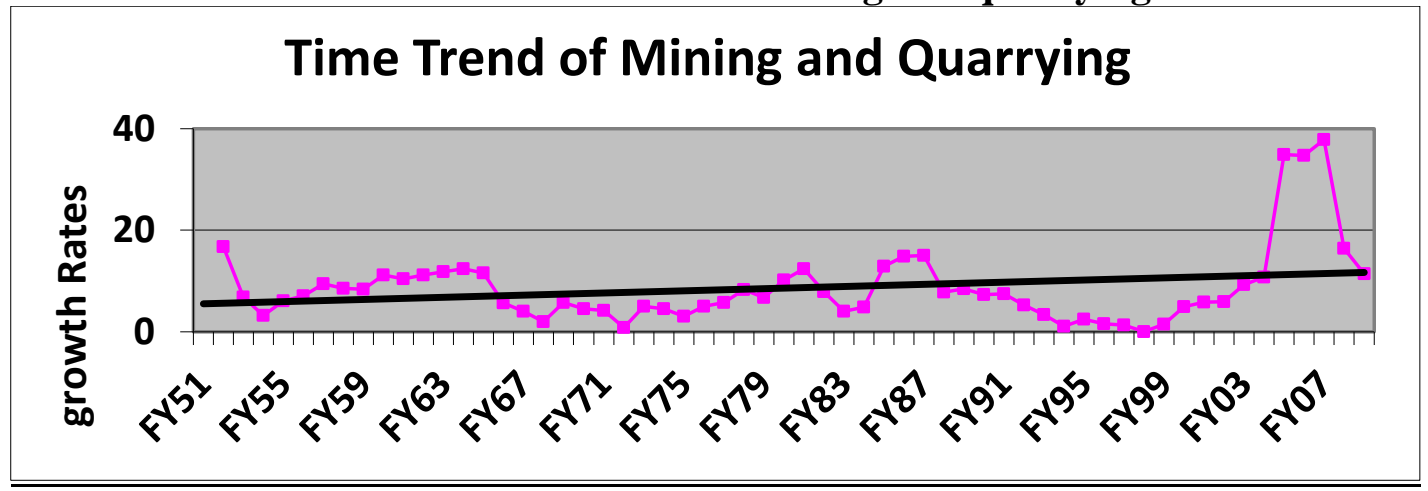

\subsection{2- Fuel Extraction Industry}

Pakistan's energy needs are met principally from natural gas, oil and coal, Hydro electricity and nuclear power. The Toot area is one of the oldest oil- producing region in Pakistan with the first oil well was drilled in 1964 that started commercial production in 1967. Pakistan first oil field was discovered in the late 1952 at Sui in Balochistan. Pakistan imports about 3 quarters of its crude oil requirements and has large reserves of natural gas at Sui in Balochistan. (www.papg.org.pk 2011)

Private sector oil and gas development is a govt. priority. The independent Oil and Gas Regulatory Authority (OGRA) started regulating the oil and gas sector in March 2002. Pakistan is also a major producer of Bituminous coal' sub- bituminous, coal and lignite. Low sulfur coal was recently reported to have been found at the Baluchistan near Quetta as well. Pakistan produced about 45 tons of Uranium in 2006 and has recently used some in its own nuclear power and weapons. Baghalchur (a small town in Dera Ghazi Khan District, Punjab, Pakistan) is the site of abandoned Uranium mines now being used as a nuclear dump. Several Pakistani environmentalist groups are bitterly opposed to the nuclear dump being used by Pakistan Atomic Energy Commission (PAEC) have asked the government to invest in better techniques in the disposal of nuclear waste materials. Sindh's Thar Desert and Neyveli (in Pakistan) lignite mines will also be expanded soon for industrial usage to Special measures are being employed 
to reduce the resulting fly ash, carbon footprint and sulphur fume emission problems after its burnt.( www.sidepad.com 2011)

\subsection{3- Manufacturing}

The manufacturing sector of any country bears significant importance. Globalization, and in particular, enhanced exports are generally believed to benefit developing countries. Manufacturing is the second largest sector of the economy of Pakistan after agriculture. The sector is dominated by textile, oil and gas, cement and automobile sectors in terms of assets size and credit allocation. Cotton textile production and apparel manufacturing are Pakistan's largest industries accounting for about 64 percent of total export. State involvement in manufacturing remains substantial especially in heavy engineering and steel. Govt. intervention in manufacturing remains targeted at protecting infant industries through tariffs and domestic support measures, including various tax concessions. The edible oil manufacturing industry is protected by relatively high specific tariff.(Iffat Ara 2004)

The manufacturing sector can be categorized into two sub-groups.

A-Large- scale manufacturing (LSM)

B- Small and medium enterprise (SME).

CHART-3-Time trend of manufacturing

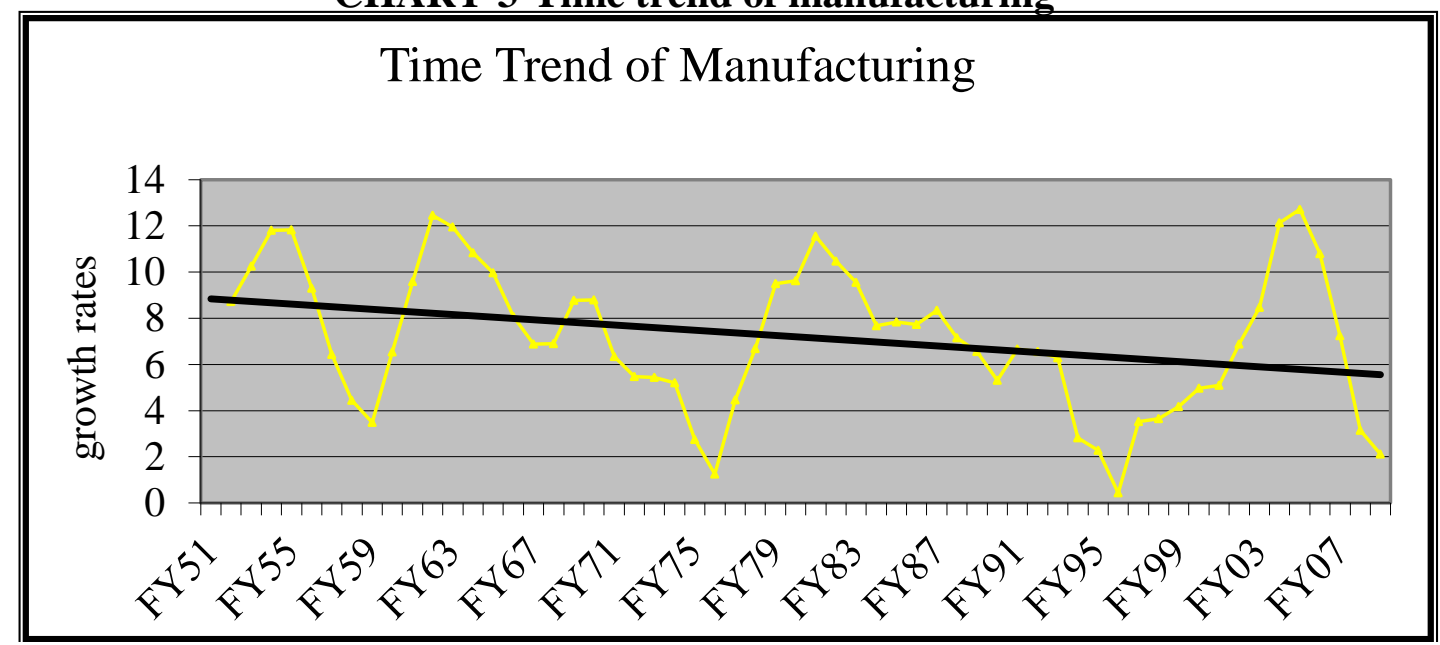

\subsubsection{1) A-Large- scale manufacturing}

This is true for the deteriorating law and order situation, energy crises; natural climates, growing input prices, and higher inflation further compound Pakistan's manufacturing sector's history as well recent 
deceleration in the sector. The group-wise performance of large-scale manufacturing shows mixed results. The performance of LSM is not satisfactory during current year as compared to last year. The major positive contribution toward modest growth performance came from durables like growth in automobiles, growth in textile group and leather products, pharmaceutical and chemical group. There seen negative growth in petroleum group, cement industries, non-metallic mineral products, steel and electronic industries. State involvement in large-scale manufacturing remains significant, although it is declining as privatization continues. Industrial policy is based on accelerating industrialization aimed at increasing manufacturing value added and share of GDP to US \$ 188 billion and 30 percent respectively, by 2030. (Economic survey of Pakistan: 2010-2011).

\section{Chart - 4-Time trend of manufacturing large-scale}

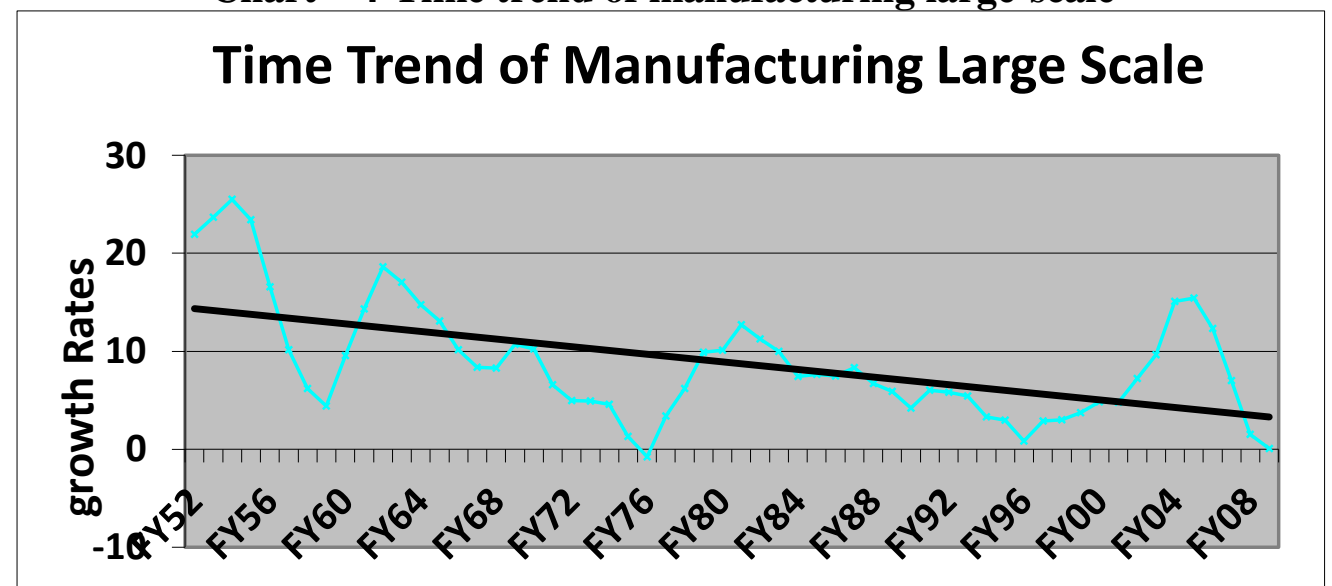

\subsubsection{2- B-Small and medium enterprise (SME)}

The SMEs are the backbone of economic growth of a developing country. Due to their sheer number, size and nature of operation, this sector of economy promotes endogenous source of growth and strengthens the infrastructure for accelerated economic expansion and development. The potential of SMEs to promote domestic- led growth in new and existing industries and to strengthen the resilience of the economy in a competitive and challenging environment are inarguable. Deposit their heterogeneity; SMEs are generally concentrated in selected activities such as: (i) Metal working, (ii) Furniture, (iii) Agro- based, (iv) Sports goods, (v) Fisheries, (vi) Poultry (vii) Gems and Jewelry and (viii) Food and Catering. In Pakistan the significant role of SMEs is clearly indicated by research and statistic. According to more recent estimates, SMEs contributes 40 percent to GDP. Significance of their role in economic development is endorsed by the fact that, in 2009-2010, a period in which real GDP of Pakistan grew by 3.8 percent the small scale sector provided much support to overall pattern and 
grew by 7.5 percent. Hence, it is clear that in time of economic downturn, SMEs outperform large enterprises providing much support to overall economic growth. (Economic survey of Pakistan; 2010-2011)

Pakistan's micro- enterprises also face many binding constraints in entry and growth phases. At the entry stage these are: (i) Fixed Capital (ii) Working Capital (iii) Recovery of credit given to customers. (iv) Access to product design. (v) Access to tools, equipments raw materials: particularly for the units in small. (vi) Access to markets: inadequate demand; more for units in small towns. (vii) Skilled labor. (viii) Taxes. (ix) Transport and communication facilities, and (x) Government regulations. In the growth phase the constraints change and so do their importance.( www.scribd.com 2011)

Chart -5- Time trend of manufacturing small scale

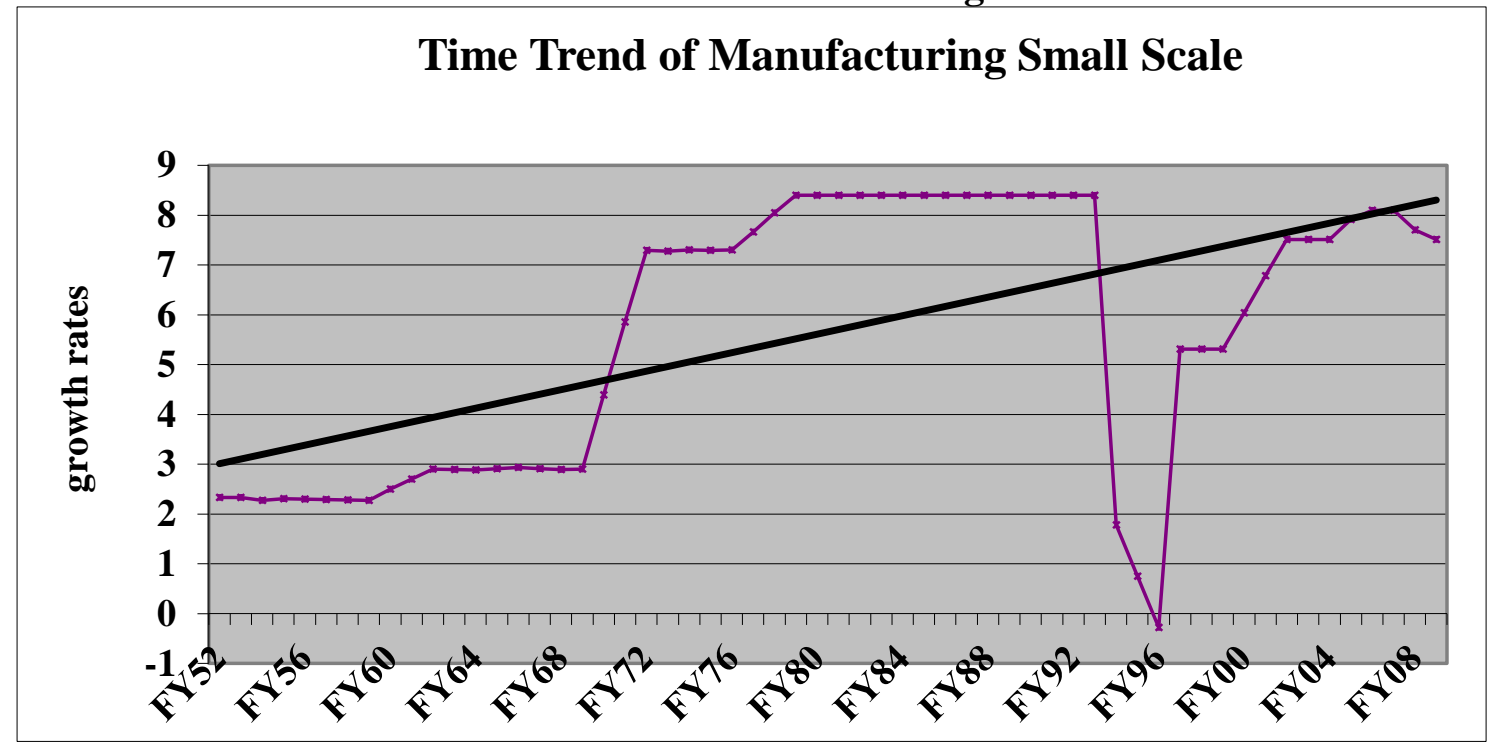

\subsection{4- Construction}

Construction sector includes hospitals, schools, townships, offices and other buildings; urban infrastructure (including water supply, sewerage, drainage); highways, roads airports, railways, ports, power systems; irrigation and agriculture systems; telecommunication etc. It deals with all economic activities directed to the creation, renovation, repair or extension of fixed assets in the form of buildings, land improvement of engineering nature. Construction and engineering services industry play an important role in the economic uplift and development of the country. Unfortunately construction sector is one of the most neglected sectors in Pakistan. Although the construction sector has only 2.3 percent share in GDP, its share of employed labor force disproportionately large at 6.1 percent in 2007. (Raza Ali Khan 2008) 
After the devastating 2005 Kashmir earthquake, the cost construction in Pakistan increase 30 to 50 percent due to implementation of new building code. The price of cement has increased by 50 percent and govt. banned export of cement. The higher demand for construction workers also reflected in a continued double-digit rise in their wages since FY2005.( Wikipedia 2009)

\section{Chart-6-Time trend of construction}

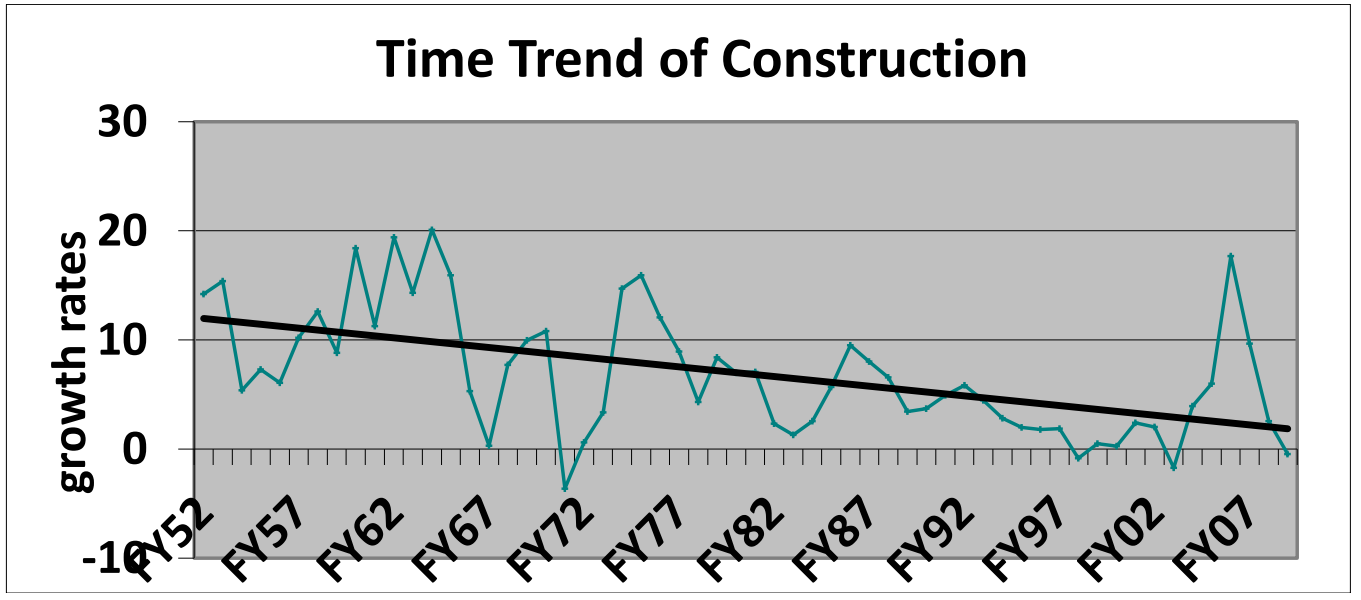

\subsection{5-Electricity, Gas and Water Supply:}

Pakistan have extensive energy resources including fairly sizable natural gas reserves, some proven oil reserves, coal (Pakistan has the fourth largest coal reserves in the world) and a large hydropower potential. However the exploration of energy resources has been slow due to a shortage of capital and domestic political constraints. Domestic petroleum production totals only about half the country's oil needs, and the need to import oil has contributed to Pakistan's trade deficits and past shortages of foreign exchange. The current govt. has announced that privatization in a gas and oil sector is a priority, as is the substitution of indigenous gas for imported oil, especially in the production of power. Pakistan is the world leader in the use of compressed natural gas (CNG) for personal automobiles.(Wikipedia 2011).

Today Pakistan is facing serious energy crises. Despite consequent rising demand of energy, no worthwhile steps have been taken to install new capacity for generation of the required energy sources. Now, the demand exceeds supply and hence "Load shedding" is a common phenomenon through frequent power shutdown. There is a shortfall of about 3000 to 4000NM per day by 2010. The shortage is badly affecting industry, commerce and daily life of people. The Govt. is understandably engaged in a vigorous effort to expand the Nation's power generation capacity through building of dams and inviting foreign investors for establishing thermal units 
in the country. Pakistan is also working to expand the use of wind turbines. Pakistan Alternative Energy Development Board (AEDB) recently approved New Park Energy Phase 1, a 400-MN wind project near Port Qasim. ( NoorUl-Haq 2006).

The Regulatory function of petroleum industry including Liquid Petroleum Gas (LPG), and Compressed Natural Gas (CNG) activities and petroleum product pricing functions were transferred to OGRA in March 2006. Pakistan is constructing several regional gas pipelines, e.g. IranPakistan- India, Turkmenistan- Afghanistan- Pakistan, and Qatar- Pakistan. Moreover, subsidy on gas was given on fertilizer industry and on chemical plants. The sector regulatory remains the National Electric Power Regulatory Authority (NEPRA).

Until the $21^{\text {st }}$ century Pakistani water sector policies were mainly focused on water resources and irrigation. This has changed with the National Drinking Water Policy (NDWP), the National Sanitation Policy (NSP) and the Clean Drinking Water for all programmes, which were prepared by the Ministry of environment as integral parts of the Medium Term Development Framework (MTDF) 2005-2010. A major shift of sector responsibility took place under the 2001 Local Government Ordinance. (Internship report on Sui Gas 2009)

Chart -7-Time trend of electricity, gas and water supply

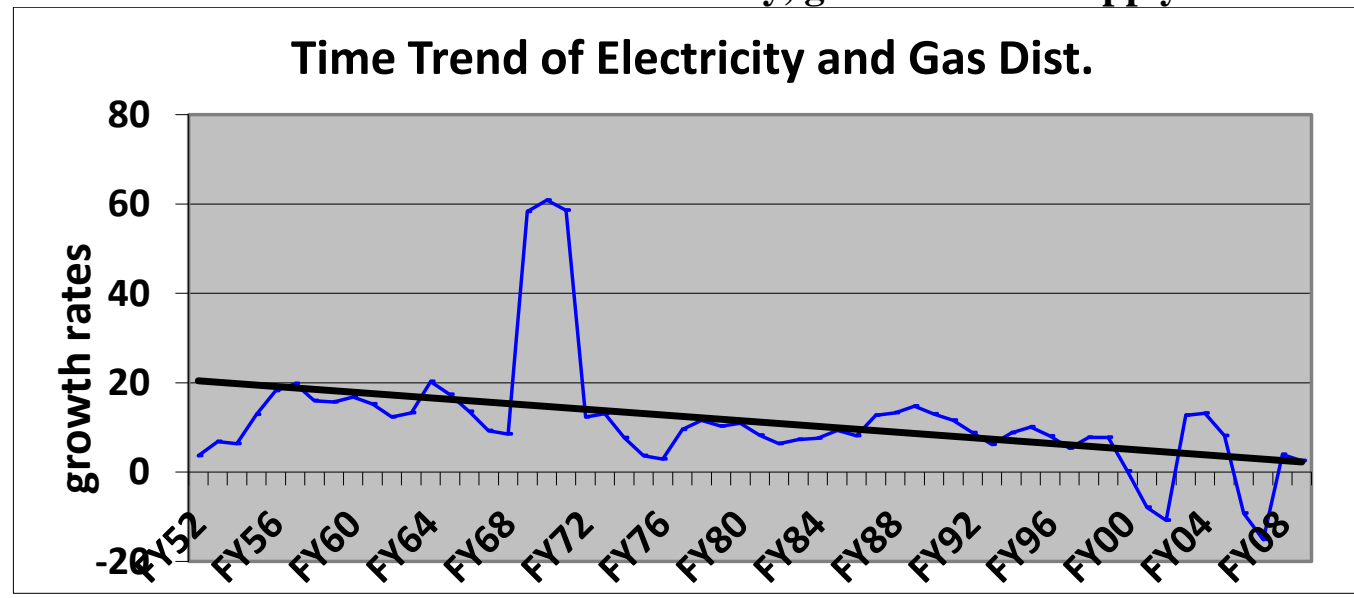

Finally, the characteristics of industrial sector of Pakistan indicate that it has rather fixed share of specific industries since last several years. Economy is growing relatively steady on an average around 7 percent. The reasons for slow and fluctuating growth were political, economic and financial shocks. On the other hand the share of relatively medium or high level of technology products remains low or decreasing over the time. Although the govt. intended to expedite the process of reforms, structural changes and integration, the political instability and war on terrorism by the 
western powers in the region the progress remained inconsistent during last several years, especially after the event of nine-eleven.( Tariq 2009)

The main objective of the study is to estimate the impact of growth in industrial sector on GDP growth. Further to suggest policy recommendation for the improvement of the sector based on the findings of the study. The study is planned to analyze the impact of industrial sector on GDP. This study includes five sections. First section explains brief introduction about topic, objective, and organization of study. Second section presents the review of existing literature, third chapter discusses the methodology used in the paper, section fourth gives the results and finally fifth section concludes the Paper and gives suggestion.

\section{2-LITERATURE REVIEW}

Sabir and Ahmed (1993) studied the impact of structural adjustment policies on TFP, concluded that, although the average growth in overall economy has declined from GDP and residential and non-residential investment, using quarterly national income and gross domestic product data for the period 1959-1992. Results showed that residential investment causes, but is not caused by GDP, while non-residential investment does not cause, but is caused by GDP. They concluded that housing leads and other types of investment lag the business cycle.

Tse and Ganesan (1997) also used the same econometric technique (Granger causality test) to determine the causal relationship between construction flows and GDP using quarterly Hong Kong data from 1983 to 1989. They found that the GDP leads the construction flow and not vice versa.

Sabir and Ahmed (2002) studied the impact of structural adjustment policies on TFP, concluded that, although, the average growth in overall TFP of the overall economy has declined from 2.8 percent in the pre-reform period (1973-88) to 0.7 percent, in the post-reform period (1988-2002), in the manufacturing sector it declined from 5.9 percent to 1.9 percent, respectively during these two periods. In addition, their results indicate that during pre- and post-reform periods, the relative contribution of TFP to overall value added has declined from 48 percent per annum to 16 percent per annum whereas in the manufacturing value added its contribution has declined from 79 percent per annum to 45 percent per annum. They also noticed that human capital has been the major factor that contributed to TFP growth during these periods.

Hoque and Musa (2002) found that period between 1994 and 2001; the IPOs of Dhaka Stock Exchange (DSE) was largely under priced at 285.21 percent. At the same period the degree of under pricing in Malaysia was 46.44 percent. 
IMF (2002) had computed TFP of the overall economy of Pakistan for the period 1961-2001. The findings indicate that, on average, TFP experienced negative growth in the 1960s, positive in the 1970s and 1980. However, in the 1990s the growth decline to just 0.6 percent per annum. Furthermore, human and physical capital has primarily bolstered the GDP growth during this period.

Pasha et. Al (2002) pointed out that the growth of TFP of the manufacturing sector shows a persistence declining trend during 1973-98, average annual growth rate of TFP declined from 9.4 percent during 196883 to meager 1.4 percent during 1993-98 per annum contribution of TFP in overall economic growth that was 55 percent during 1968-83 declined to as low as 16 percent. They further concluded that human capital has played a leading role in the growth of TFP of manufacturing sector, of the 4.6 percent annum growth of TFP during 1973-98, 1.8 percent was the contribution by human capital.

Wizarat (2002) computed total factor production (TFP) of the large scale manufacturing sector for the period 1951-91. Her results show an increase in TFP trend. Moreover, she found that the contribution of TFP to economic growth has been negative (-27 percent), on average, during the period 1955-91. According to her study economic growth was largely driven by capital ( 88 percent) and labor (40 percent).

Ghosh and Maji (2003) examined the efficiency of working capital of the Indian cement companies during 1992-1993 to 2001-2002. For measuring the efficiency of working capital management, performance, utilization, and overall efficiency indices were calculated instead of using some common working capital management ratios. Setting industry norms as target-efficiency levels of the individual firms, and also tested the speed of achieving that target level of efficiency by an individual firm during the period of study. It was found that the Indian Cement Industry as a whole did not perform remarkably well this period. Eljelly and Abuzar (2004) empirically examined the linkage of profitability, as indicated by the current ratio and cash cycle. They studied a sample of Saudi Arabian companies covering the years 1996 to 2000. They find a significant inverse relationship between company profitability and liquidity, while a direct strong relationship was identified between company size and profitability.

Iffat Ara (2004) assessed the competitiveness of manufacturing sector of Pakistan by comparing the trend in the growth of factor and non-factor input prices with that of export price and also looked at the trend in the growth of productivity. She found that over the period 1972-73 to 2002-2003, both the factor and non-factor prices have grown at a rate higher than that of general price level as well as of export price. She further suggest that even though 
the growth in productivity is offsetting the negative impact of the growth in input factor prices, the growth in productivity itself depicts a declining trend especially for the most recent period, 1999-03.

Shah and Sana (2006) used a very small sample of 7 oil and gas sector firms to investigate this relationship for period 2001-2005. The results suggested that managers could generate positive return for the shareholders by effectively managing working capital.

Lazaaridis and Tryfonidis (2006) investigated the relationship of corporate profitability and working capital management for firms listed at Athens Stock Exchange. They reported that there is statistically significant relationship between profitability measured by gross operating profit and the Cash Conversion Cycle. Furthermore, Managers can create profit by correctly handling the individual components of working capital to an optimal level.

Rehman (2006) investigated the impact of working capital management on the profitability of 94 Pakistani firms listed at Islamabad Stock Exchange (ISE) for a period of 1999-2004, and studied the impact of the different variables of working capital management including Average Collection Period, Inventory Turnover in Days, Average Payment Period and Cash Conversion Cycle on the Net Operating Profitability of firms. It is found that there is a strong negative relationship between above working capital ratios and profitability of firms. Furthermore, manager can create a positive value for the shareholders by reducing the cash conversion cycle up to an optimal level.

Padachi (2006) has examined the trends in working capital management and its impact on firm's performance for 58 Mauritian small manufacturing firms during 1998 to 2003. He explained that a well designed and implemented working capital management is expected to contribute positively to the creation of firm's value. The results indicated that high investment in inventories and receivables is associated with low profitability and also showed an increasing trend in the short term component of working capital financing.

Islam, Ali and Ahmed (2006) investigate the behavior of initial public offerings of the Dhaka Stock Exchange during the period of 1995-2005.They studied 117 companies and find the 102 IPOs were under priced, 13 over priced while only 2 were accurately priced.

Rehman and Nasr (2007) analyzed profitability and working capital management performance of only 94 firms listed on Karachi Stock Exchange for period 1999-2004 only by using Ordinary Least Square and Generalized Least Square. Their findings of study suggested that there exist a negative relationship between working capital management measures and profitability. 
Afza and Nazir (2007) investigated the relationship between aggressive and conservative working capital policies for a large sample of 205 firms in 17 sectors listed on Karachi Stock Exchange during 1998-2005. They found a negative relationship between the profitability measures of firms and degree of aggressiveness of working capital investment and financing policies.

M. Shahbaz and N. Aamir (2007) analyzed the direct foreign investment and income distribution for Pakistan for period from 1970-2005. Their study is a pioneering effort regarding country case like Pakistan. They used modern technique in finding the order of integration for running actors. They used ARDL bounds approach and error correction method (ECM). Their findings reveal that increased FDI in Pakistan worsens income distribution because it is focused towards capital intensive industrial and services sectors of urban localities.

K.M.Yousaf Tariq (2008) used the data from 1990 to2007 and find that trade liberalization reforms since 1998 have not changed the composition of exports of Pakistan's manufacturing sector.

Khan Ali Raza (2008) investigate the role of constructio0n sector in economic growth by using co-integration and Granger casualty test find that there is strong casual relationship between the aggregate economy and the construction sector of Pakistan. He used annual data for construction sector and economic GDP of Pakistan from 1950 to 2005.

Rehman A. et al (2008) analyzed the working capital management and corporate performance of manufacturing sector in Pakistan. They used panel data from 1998 to 2007 and conclude that firms in Pakistan are following conservative working capital management policy and the firms are needed to concentrate improve their collection and payment policy.

Usman, (2008) investigate the impact of oil price and exchange rate volatility on economic growth in Nigeria on the basis of quarterly data from 1986Q1 to 2007Q4. He analyzed the time series properties of the data by examining the nature of causality among the variables. Furthermore, he applied Johansen VAR-based co integration technique and vector error correlation model. The result showed unidirectional causality from oil prices to real GDP and bidirectional causality from real exchange rate to real GDP and vice versa.

Afza and Nazir (2009) investigated the working capital management efficiency of cement sector of Pakistan for the period 1988-2008. Instead of employing the traditional ratios, they measured the working capital efficiency in terms of utilization index, performance index and total efficiency index as suggested by Bhattacharya (1997). Findings of the study indicate that the cement sector as a whole did perform well during the study period. 
Samreen, Khalid and Aslam (2009) investigated the potential impact of coal on electricity generation and economic growth of Pakistan. They used secondary data from 1995 to 2007 and applied OLS technique attributed to Carl Friedrichgauss. The result showed that coal is efficient estimator then other energy resources; there is positive relation between electricity generation and coal.

Khuram Khan et. Al (2009) examined the affect of corporate governance on a firm's performance. Their research had been carried out on the Tobacco industry of Pakistan and focused on three aspects namely ownership concentration, CEO duality and Board's Independence. They had been used data from three listed companies of the Tobacco industry, namely Pakistan Tobacco, Lakson Tobacco and Khyber Tobacco for the period 2004-2008. They had been measured Firm's performance through Return on Equity (ROE) \&Return on Assets (ROA). They conclude that there is strong and positive impact of corporate governance on firm's performance.

IO Chhappra and NA Naqui (2009) investigated the relationship between the Working Capital Management (WCM) and firm's profitability in the textile sector of Pakistan. They selected a sample size of 55 textile companies in Pakistan for a period of six years, from 2003 to 2008 and used correlation, regression analyses and ANOVA Test. Their results showed a strong positive significant relationship between WCM and firm's profitability and a significant negative relationship between debt used by the firm and its profitability in Pakistan's textile sector.

Udah, Enang B (2009) investigate the causal and long-run relationship between electricity supply, industrialization and economic development in Nigeria from 1970-2008. To achieve this, he used time series data and employed the Granger Causality test and the ARDL bounds test approach to co integration proposed by Pesaran et al (2001). The Granger Causality results showed that there is a feedback relationship between GDP per capita and electricity supply, and no causal link in the case of industrial output and GDP per capita.

Bedi-uz-Zaman, M.Farooq and Sami Ullah (2009) investigate the sectoral oil consumption and economic growth in Pakistan for the period of 1972-2008. They used different time series techniques, the result showed that major sectors of oil consumption (transportation, power generation and industry) are positively contributing.

Umer Sheraz (2010) worked on Mining Futures: Beyond the headlines, in his article he used the six pillars method of future studies to address the futures of mining from multiple aspects. He conclude that mining is more than just technology or economics of pricing and sound policies initiatives are needed to direct society and re-think current trends in international governance of resource use, and material-intensive life styles., 
while the minor sectors of oil consumption (household, government and agriculture) are negatively contributing in economic growth.

\section{3-METHODOLOGY AND DATA}

This section discusses the methodologies that are employed to meet the objectives of the study. The variables used in this study of impact of industrial sector on GDP include growth of gross domestic product (gGDP), dependent variable, and growth of industrial sector (gIND), growth of mining and quarrying (gMQ), growth of manufacturing (gMANF), growth of manufacturing large -scale (gMNLS), growth of manufacturing smallscale (gMNSS), growth of construction (gCONS), growth of electricity, gas and water supply distribution (gEGD) as a independent variables.

The sample period covers time series data from 1950 to 2010. All the relevant data is obtained from Economic Survey of Pakistan, Pakistan Bureau of Statistic and State Bank of Pakistan.

Many economic time series are non-stationary at levels. One way of getting the interesting information about the stationarity of time series is to plot the original series and making correlogram at both level and first difference. The second, most rigorous way is to use the Augmented Dickey Fuller (ADF) which is the wider version of the standard Dickey Fuller (DF). This test is employed to verify the presence of unit root in the series.

\section{1-IMPLICATION OF STAIONARY AND NON-STATIONARTY TIME SERIES}

As we begin to develop models for time series, we want to know whether the underlying stochastic process that generated the series can be assumed to be invariant with respect to time. If the characteristics of stochastic process change over time, i.e., if the process is non-stationary, it will often be difficult to represent the time series over past and future intervals of time by a simple algebraic model---the random walk with drift is an example of non-stationary process for which a simple forecasting model can be constructed. By contrast, if the stochastic process is fixed in time, i.e., if it is stationary then one can model the process via an equation with fixed coefficients that can be estimated from past data.

Observing the results of Unit-Root Test in the result section; it is clear that all the data series are stationary at same level. So when data series are stationary, we can use the Ordinary Least Square Method to regress the series to get results. The method of ordinary least squares is attributed to Carl Friedrichgauss, a German mathematician. Under certain assumptions, the method of least squares has some very attractive statistical properties that have made it one of the most powerful and popular methods of regression analysis (Damodar, Gujrati and Sangeetha, 4th ed). 


\section{2-LEAST SQUARE METHED FOR (REGRESSION)}

Least squares or ordinary least square (OLS) is a mathematical optimization technique which, when given a series of measured data, attempts to find a function which closely approximates the data (a "best fit"). It attempts to minimize the sum of the squares of the ordinate differences (called residuals) between points generated by the function and corresponding points in the data. Specifically, it is called least mean squares (LMS) when the number of measured data is 1 and the gradient descent method is used to minimize the squared residual. LMS is known to minimize the expectation of the squared residual, with the smallest operations (per iteration). But it requires a large number of iterations to converge.

\section{3- MATHEMATICAL PRESENTATION OF MODEL}

To test the relationship between gross domestic product and different components of the industrial sector following model is used:

gGDP $=f$ (gIND, gMQ, gMANF, gMNLS, g MNSS, gCON, g EGD, $\varepsilon$ ) gGDP : Growth of Gross Domestic Product

gMQ: Growth of Mining and Quarrying. gMANF: Growth of manufacturing sector.

gMNLS: Growth of large-scale manufacturing sector.

gMNSS: Growth of small and medium enterprises sector.

gCON: Growth of construction industry.

gEGD: Growth of electricity, gas and water supply sector.

$\varepsilon: \quad$ Error term.

\section{4- Model Specifications}

$\mathrm{gGDP}=\mathbf{\beta 0}+\mathbf{\beta 1}(\mathrm{gIND})+\mathbf{\beta 2}(\mathrm{gMQ})+\mathbf{\beta 3}(\mathrm{gMANF})+\mathbf{\beta 4}(\mathrm{gMNLS})+\mathbf{\beta 5}$

$(\mathrm{gMNSS})+\mathbf{\beta 6}(\mathrm{gCON})+\mathbf{\beta 7}(\mathrm{gEGD})+$

\section{5-Data Analysis and Discussions}

This section includes descriptive as well as quantitative analysis and results of these two types of analysis are discussed in this section.

\section{6- Quantitative Analysis}

For analysis of data one method is used in this study: that is regression. Initially regression is used to check the impact of different independent variables on the dependent variable and also to test significance of this impact. 


\section{4-RESULTS AND DICUSSION}

\section{1-ANALYSIS OF RESULTS OF UNIT ROOT (TABLE 4.1):}

To test the stationary we have used ADF test because DF test is based only on AR (1) process while ADF test extra lagged terms of dependent variable in order to eliminate auto-correlation. In table (4.1) I tested the null hypothesis of unit root against alternative of stationary at level or first difference.

The augmented Dickey-Fuller (ADF) statistic, used in the test, is a negative number. The more negative it is, the stronger the rejection of the hypothesis, that there is unit root, at some level of confidence. In one example, with three lags, a value of -3.17 constituted rejections at the pvalue of 10 percent.

Results show that all the variables are stationary at level when order of integration is I (1) and intercept \& trend are considered. OLS estimation technique is applied to calculate the results.

Table 4.1 ADF Test Results of Industrial Sector Components and GDP.

\begin{tabular}{|c|c|c|c|c|}
\hline \multirow[b]{2}{*}{ Variables } & \multicolumn{2}{|c|}{ Level } & \multicolumn{2}{|c|}{ First Difference } \\
\hline & $\begin{array}{c}\text { Intercept } \\
\text { and Trend }\end{array}$ & $\begin{array}{c}\text { Order } \\
\text { of Integration }\end{array}$ & $\begin{array}{c}\text { Intercept } \\
\text { and Trend }\end{array}$ & $\begin{array}{c}\text { Order } \\
\text { of Integration }\end{array}$ \\
\hline gIND & $\begin{array}{l}-4.94 * \\
(-4.13) \\
\end{array}$ & $\mathrm{I}(1)$ & $\begin{array}{c}-7.67 * \\
(-4.13) \\
\end{array}$ & $\mathrm{I}(0)$ \\
\hline gMQ & $\begin{array}{l}-3.84 * * \\
(-3.50) \\
\end{array}$ & $\mathrm{I}(1)$ & $\begin{array}{l}-7.55^{*} \\
(-4.13) \\
\end{array}$ & $\mathrm{I}(0)$ \\
\hline gMANF & $\begin{array}{l}-5.04^{*} \\
(-4.13)\end{array}$ & $\mathrm{I}(1)$ & $\begin{array}{l}-7.73 \\
(-4.13)\end{array}$ & $\mathrm{I}(0)$ \\
\hline gMNLS & $\begin{array}{l}-4.78^{*} \\
(-4.13)\end{array}$ & $\mathrm{I}(1)$ & $\begin{array}{l}-7.84 * \\
(-4.13)\end{array}$ & $\mathrm{I}(0)$ \\
\hline gMNSS & $\begin{array}{c}-3.26 * * * \\
(-3.17) \\
\end{array}$ & $\mathrm{I}(1)$ & $\begin{array}{l}-7.91 * \\
(-4.13)\end{array}$ & $\mathrm{I}(0)$ \\
\hline gCONS & $\begin{array}{c}-4.31 * * * \\
(-4.13)\end{array}$ & $\mathrm{I}(1)$ & $\begin{array}{l}-6.54 * \\
(-4.13)\end{array}$ & $\mathrm{I}(0)$ \\
\hline gEGD & $\begin{array}{l}-5.00 * \\
(-4.13) \\
\end{array}$ & $\mathrm{I}(1)$ & $\begin{array}{l}-7.24 * \\
(-4.13) \\
\end{array}$ & $\mathrm{I}(0)$ \\
\hline gGDP & $\begin{array}{c}-3.33 * * * \\
(-3.17)\end{array}$ & $\mathrm{I}(1)$ & $\begin{array}{l}-7.03 * \\
(-4.13) \\
\end{array}$ & $\mathrm{I}(0)$ \\
\hline
\end{tabular}

Note: $*$ denotes the rejection of the null hypothesis at 1 percent level of significance, $* *$ denotes the rejection of the null hypothesis at 5 percent level of significance and $* * *$ at 10 percent level of significance. Values in the parenthesis are MacKinnon critical values for rejection of hypothesis of a unit root. Legend: - gMQ is growth in mining and Quarrying, gMANF is growth in manufacturing, gMNLS is growth in manufacturing large scale, 
gCONS is growth in construction and gEGD stands for growth in electricity and gas distribution.

\section{2-ANALYSIS OF RESULTS OF REGRESSION}

Simple linear regression technique is used to analyze the impact of different determinants one by one. However results have been shown in table 4.2. It is also used here to avoid the issue of co integration to the maximum extent.

Table 4.2:- Results of regression by using model equation (3.4)

\begin{tabular}{|c|c|c|c|c|c|c|c|}
\hline & gMQ & gMANF & gMNLS & gMNSS & $\mathrm{gCON}$ & gEGD & $\begin{array}{c}\text { Overall } \\
\text { gIND }\end{array}$ \\
\hline Constant & $\begin{array}{c}5.08 \\
(17.73)\end{array}$ & $\begin{array}{c}2.18 \\
(3.94)\end{array}$ & $\begin{array}{c}2.25 \\
(3.67)\end{array}$ & $\begin{array}{c}4.19 \\
(9.35)\end{array}$ & $\begin{array}{c}4.09 \\
(9.80)\end{array}$ & $\begin{array}{c}4.20 \\
(9.84)\end{array}$ & $\begin{array}{c}2.60 \\
(4.35)\end{array}$ \\
\hline GGDP & $\begin{array}{c}-0.01 \\
(-0.93)\end{array}$ & $\begin{array}{c}0.20 \\
(5.19)\end{array}$ & $\begin{array}{c}0.17 \\
(4.66)\end{array}$ & $\begin{array}{c}0.06 \\
(1.94)\end{array}$ & $\begin{array}{c}\text { 0.06 } \\
(2.43)\end{array}$ & $\begin{array}{c}0.04 \\
(2.07)\end{array}$ & $\begin{array}{c}0.16 \\
(4.17)\end{array}$ \\
\hline $\mathbf{R}^{2}$ & 0.01 & 0.31 & 0.27 & 0.060 & 0.09 & 0.07 & 0.23 \\
\hline
\end{tabular}

Regressions estimated using data for 1950-2010. Number of observations is 59 after adjusting endpoints. $T$ values are given below the coefficient estimate in each cell.

There is positive relation between growth in GDP and Industrial Sector. The R- square value of about 0.22 which means 22 percent of the variation in GDP growth is explained by the growth in industrial sector.

There is negative relationship between growth in mining and quarrying sector and GDP. The R-square value of about 0.014 its means that 1 percent of the variation in GDP growth is explained by the growth in mining and quarrying sector.

There is a positive relation between GDP growth and growth in manufacturing sector. The R- square values of about 0.31 its means that 31 percent of the variation in a GDP Growth is explained by the growth in manufacturing sector.

There is a positive relationship between GDP growth and growth in large-scale manufacturing. The R-square value of about 0.27 states 27 percent of the variation in GDP growth is explained by the growth in largescale manufacturing.

There is a positive relationship between growth in small- scale manufacturing and GDP. The R-square value of about 0.06 shows that 6 percent of the variation in GDP growth is explained by the growth in smallscale manufacturing.

There is a positive relationship between growth in construction sector and growth in GDP.The R-square value of about 0.09 states that 9 percent of 
the variation in GDP growth is explained by the growth in construction sector.

There is a positive relationship between electricity, gas and water supply sector and GDP growth. The R-square value of about 0.07 shows that 7 percent of the variation in a GDP growth is explained by the increase in growth of electricity, gas and water supply sector.

\section{5-CONCLUSION AND RECOMMENDATION 5.1- CONCLUSION}

This paper is an attempt to investigate the relationship between economic growth and different components of industrial sector of the economy of Pakistan. Secondary data for 61 years from 1950 to 2010 was used for this purpose. The first step in the empirical analysis involves testing the time series characteristics of the data series using ADF tests. Simple linear regression and time series techniques are applied to estimate the relationships. All the variables used in this study are stationary in their first differences.

Regarding the hypotheses of the study it is concluded that the entire hypothesis has a positive impact on GDP partially accepted. Because in simple linear regression all the component of industrial sector shows a positive relationship with GDP except mining and quarrying sector that not only shows the negative relationship but also gives an insignificant result. All other results are statistically significant and consistent in simple linear regression.

\section{2- RECOMMENDATIONS}

I wish to suggest the following steps in order to improve the industrial output:

Small firms are generally inefficient and have to be made efficient through proper policy support and guidance. Small industry needs to be made buoyant and progressive partner in development process. The best way to do so is to establish strong small-large links in production, wherever feasible. Large- Small links may not get established automatically, they are to be developed with Government policy support.

There is need for Pakistan industrial sector to focus on: (a) develop of new products; (b) import replacements; (c) export goods; and (d) goods with growing demand. It would be appropriate to put the scarce national resources, in particular, capital to use for the production of new products rather than duplicate lines of production that are being carried on, even with inefficiencies.

To achieve higher growth, special incentives may be provided for setting up of industries for the manufacture of international quality. A system 
to transfer technology to industry for commercialization, promote export centers for industrial development. The government of Pakistan has to secure continuous flow of Gas and Electricity to business without frequent load shedding. Government investment is required in improving Pakistani infrastructure within the country. Government should develop a reasonable infrastructure and other ancillary facilities.

\section{Refrences:}

Afza and Nazir (2009). "Working Capital Management: Efficiency of Cement Sector of Pakistan". Journal of Economics and Behavioral Studies Vol. 2, No. 5, pp. 223-235, May 2011.

Aamir and Shabaz (2007)." Direct Foreign Investment and Income Distribution: A Case Study for Pakistan". International Research Journal of Finance And Economics ISSN 1450-2887 Issue 21 (2008).

A.R.Usman (2008). Impact of Oil Price Shock and Exchange Rate Volatility On Economic Growth in Nigeria: An Empirical Investigation. Research Journal of International Studies- Issue 11 (July 2009).

Afza and Nazir (2007). Working Capital Management Policies of Firms: Empirical Evidence from Pakistan. Conference Proceedings of $9^{\text {th }}$ South Asian Management Forum (SAMF) on February 24-25, North South University, Dhaka, Bangladesh.

Ara Iffat (2004) Is Pakistan's manufacturing sector competitive? The Pakistan Development Review 43:4-2,685-706

Anaman and Amponsah (2007). Analysis of the causality links between the Growth of the construction industry and the growth of the macro economy in Ghana, Institute of Economic Affairs Accra, Ghana.

B. E. Udah (2009). Industrial Development, Electricity Crises and Economic Performance: A Case Study of Nigeria. European Journal of Economics, Finance and Administrative Sciences ISSN 1450-2275 Issue 18 (2010). Chhapra and Naqui (2009). Relationship between Efficiency levels of Working Capital Management and Profitability: Case of Firms in the textile sector

Of Pakistan. Indus Journal of Management and Social Sciences, 4 (1): 3042 (spring 2010)

Eljely, M. A. (2004). Liquidity - Profitability Tradeoff: An empirical investigation in An emerging market. International Journal of Commerce and Management..

Economic Survey of Pakistan (2010-2011). Islamabad: Manufacturing and Mining

Economic Survey of Pakistan (2010-2011). Islamabad: Overview of the Economy 
Ghosh and Maji (2003). Working Capital Management Efficiency: A Study on the Indian Cement Industry. The Institute of Cost and Works Accountants of India, 39 (5): 363-372.

International Monetary Fund (2002) "Pakistan: Selected Issues and Statistical.Appendix', Country Report, No. 02/247.

Khan Khuram, Nemati and Iftikhar (2009). Impact of Corporate Governance on Firm Performance: Evidence from the Tobacco Industry of Pakistan. International Research Journal of Finance and Economics ISSN 1450-2887 Issue 61(2011).

Aslam, Khalid and Samreen (2009). The Potential Impact of Coal on: Electricity Generation and Economic Growth of Pakistan. Far East Journal of Psychology and Business Vol. 2 No. 3, March 2011.

Khan Ali Raza (2008). "Role of Construction sector in Economic Growth: Empirical Evidence from Pakistan Economy". First international conference on construction in developing countries. 4-5 August, 2008 Karachi Pakistan 279-290.

Lazaridis, and Tryfonidis (2006). Relationship between Working Capital Management and Profitability: of Listed Companies in the Athens Stock Exchange. Journal of Financial Management and Analysis. 19 (1), 26-35.

Mehmood (2004). Export Competiveness and comparative advantage of Pakistan's Non-agricultural production sector: trends and analysis. The Pakistan Development Review 43: 4-2, 541-501.

M. S. Badar, et Al. (2008). Technology Foresight for Industry Sector: A Strategy for Sustainable Development. International Journal of Business And Social Science. Vol. 2 No. 11[Special Issue- June 2011].

Pasha et Al, (2002). "The Slowing Down of the Growth of total Factor Productivity in Pakistan." Social Policy and Development Centre Research Report No. 44.

Padachi K. (2006). Trends in Working Capital Management and Its Impact on Firms' Performance: An Analysis of Mauritian Small Manufacturing Firms. International Review of Business Research Paper, 2(2): 45-58.

Pakistan Economic Survey, Ministry of Finance, Economic Adviser's Wing, several Islamabad Pakistan (Several issues).

Rehman and Nasr. Working Capital Management and Profitability - Case Of Pakistani Firms. International Review of Business Research Paper, 3(1), 279-300.

Rehman, A. (2006). Working Capital Management and Profitability: Case of Pakistani Firms. Pakistan: COMSATS Institute of Information Technology Islamabad.

Rehman, A. et Al (2008). Working Capital Management and Corporate Performance of Manufacturing: A Case Study of Pakistan. International Journal of Finance and Economics ISSN 1450-2887 Issue 47 (2010). 
Sheraz, U (2010). Mining Futures: Beyond the Headlines. Journal of Futures Studies, November 2010, 15(2): 17-32.

Shah and Sana, (2006). Impact of Working Capital Management on the Profitability of Oil and Gas Sector of Pakistan. European Journal of Scientific Research. 15(3), 301-307.

Sabir and Masood (2003). "Macroeconomic Reforms and Total Factor Productivity Growth in Pakistan: An Empirical Analysis." SPDC Conference Paper No. 55, presented at $56^{\text {th }}$ International Atlantic Economic Conference held Quebec City, Canada, 16-19 October 2003.

Tse, R. Y. C. and Ganesan (1997). Causal relationship between construction ows and GDP: evidence from Hong Kong and Economics, 15, 371-6. "The State of Pakistan's Economy". Third Quarterly Report for FY07.

Ullah Sami, Farooq M. and Zaman B. (2009). Sectoral Oil Consumption and Economic Growth in Pakistan: An ECM Approach. American Journal of Scientific Research 2011, 2(2): 149-156.

Wizarat Shahida (2002). "The Rise and fall of Industrial Productivity in Pakistan", Oxford University Press, Karachi.

www. Wikipedia. com. "Economy of Pakistan (2010). 